\title{
Improved tolerance of wheat plants (Triticum aestivum L.) to drought stress and rewatering by the arbuscular mycorrhizal fungus Glomus claroideum: Effect on growth and cell membrane stability
}

\author{
José Beltrano* and Marta G. Ronco
}

Instituto de Fisiología Vegetal, Universidad Nacional de La Plata. C.C. 327, 1900 La Plata, Argentina. *Corresponding author:beltrano@netverk.com.ar

Received: 31 August 2007; Returned for revision: 06 December 2007; Accepted: 19 February 2008

\begin{abstract}
The aim of this paper was to investigate the contribution of the arbuscular mycorrhizal fungus Glomus claroideum to drought stress tolerance in wheat plants grown under controlled conditions in a growth chamber, and subjected to moderate or severe water stress and rewatering. Water stress tolerance was determined through total dry weight, leaf relative water content, leakage of solutes and leaf chlorophyll and protein concentrations in mycorrhizal and nonmycorrhizal wheat plants. Total dry weight and leaf chlorophyll concentrations were significantly higher in mycorrhizal plants after moderate or severe water stress treatments compared with non-mycorrhizal ones. Electrolyte leakage was significantly lower in water-stressed inoculated plants. Compared to non-inoculated plants, leaf relative water content and total protein concentration of inoculated individuals increased only under severe water stress. When irrigation was re-established, mycorrhizal plants increased their total dry weight and leaf chlorophyll concentration, and recovered cell membrane permeability in leaves compared with non-mycorrhizal plants. In conclusion, root colonization by $G$. claroideum could be an adequate strategy to alleviate the deleterious effects of drought stress and retard the senescence syndrome in wheat.
\end{abstract}

Key words: mycorrhizae, relative water content, rewatering, solute leakage, water deficit

A melhoria da tolerância do trigo (Triticum aestivum L.) ao estresse hídrico e à reidratação pelo fungo micorrízico arbuscular (Glomus claroideum): Efeito sobre o crescimento e estabilidade das membranas celulares: O objetivo do trabalho foi pesquisar a contribuição do fungo micorrízico arbuscular Glomus claroideum à tolerância ao déficit hídrico em plantas de trigo cultivadas sob condições controladas em uma câmara de crescimento, submetidas ao estresse hídrico moderado ou severo e reidratação. A tolerância das plantas ao estresse hídrico foi determinada mediante o peso seco total, conteúdo relativo de água foliar, extravasamento de solutos e concentrações foliares de clorofilas e proteínas totais nas plantas de trigo micorrizadas e não-micorrizadas. O peso seco total e a concentração de clorofila foram significativamente maiores nas plantas micorrizadas sob estresse hídrico moderado ou severo, quando comparadas com as não-micorrizadas. $\mathrm{O}$ extravasamento de solutos foi significativamente menor nas plantas inoculadas estressadas. $\mathrm{O}$ conteúdo relativo de água foliar e a concentração de proteínas totais nas plantas inoculadas aumentaram apenas em condições de estresse hídrico severo. Após a re-irrigação, nas plantas micorrizadas, houve aumento do peso seco total e da concentração de clorofilas, além da recuperação da integridade das membranas celulares, quando comparadas com as plantas não-micorrizadas. Em suma, a colonização das raízes por G. claroideum poderia ser uma estratégia adequada para reduzir os efeitos deletérios do estresse hídrico e retardar a síndrome da senescência em trigo.

Palavras-chave: conteúdo relativo de água, déficit hídrico, extravasamento de solutos, micorrizas, reidratação 


\section{INTRODUCTION}

Wheat (Triticum aestivum L.) is an important crop in the Argentinean southeastern Pampa, where high temperatures and water stress often reduce plant growth and crop yields (Beltrano et al., 2006). Drought is a complex phenomenon, and is considered one of the most important factors limiting crop yields around the world. During water stress, soil water is more strongly retained and solute transfer to plants is less efficient and may not meet nutrient demands of the plants. The response of plants to water stress depends on several factors such as developmental stage, severity and duration of stress and cultivar genetics. Common plant symptoms after water deficit are stunted growth, limited $\mathrm{CO}_{2}$ diffusion to chloroplasts by stomatal closure, reduced photosynthesis rate, and accelerated leaf senescence. Moreover, in wheat, a severe water stress during the late growth stages (anthesis-post anthesis) cause chlorophyll loss, cell solute leakage, flag leaf yellowing and accelerated ear and grain maturation (Beltrano et al., 1994, 1999). Water stress also causes severe alterations in cell membrane properties including selective permeability (leakage of cell solutes), fluidity and microviscosity (Navarri-Izzo et al., 1993; Beltrano et al., 1994, 1999).

Arbuscular mycorrhizal fungi (AMF) can establish beneficial symbiotic association with many plant species, enhancing nutrient transfer and offering bioprotection activity against pathogens and drought stress (Jeffries et al., 2003). Arbuscular mycorrhizal fungi symbiosis contributes to enhance growth and vigor of plants, and can alter plant water relations, particularly during water stress periods (Ruiz-Lozano et al., 1995; Augé, 2001). Leaf water potential and leaf relative water content are important parameters to estimate cell turgor pressure and osmotic potential, and thereby quantitate tissue hydration or water status. Although AMF symbiosis cannot affect leaf water potential in non-stressed plants (Goicoechea et al., 2005), mycorrhizal plants may enhance water-use efficiency; in addition plants recover faster after water stress than non-mycorrhizal plants (Al-Karaki et al., 2004). Porcel and Ruiz-Lozano (2004) found that leaf water potential was higher in stressed mycorrhizal plants $(-1.9 \mathrm{MPa})$ than in non-mycorrhizal stressed ones $(-2.8$ $\mathrm{MPa})$. The mechanisms involved in water uptake by the AMF symbiosis include regulation of stomatal conductance, an increase in stomatal sensitivity to leafair vapor pressure deficit, and lowering leaf osmotic potential for turgor maintenance (Sánchez-Blanco et al., 2004). Arbuscular mycorrhizal fungi colonization has been shown to increase wheat drought resistance (AlKaraki et al., 2004). Cellular membrane stability, measured as the conductivity of electrolytes leaking from leaf disks at high temperature, has been suggested as a screening technique to determine heat tolerance in plants (Sullivan, 1972). Several studies have suggested the effectiveness of this technique in detecting genetic variability in heat tolerance in crops such as soybean (Martineau et al., 1979), sorghum (Sullivan, 1972), wheat (Saadalla et al., 1990), Kentucky bluegrass, salt-stressed maize (Feng et al., 2002), and drought-stressed wheat (Beltrano et al., 2006).

The range of responses of wheat to AMF and drought resistance of inoculated plants have been investigated by Hetrick et al. (1996), who reported significant differences in responses to AMF among wheat cultivars. However, no information has been reported regarding the effects of AMF during moderate or severe water stress and after rewatering. The experimental hypothesis of this study was that the mycorrhization maintains the cell membrane stability, delays senescence and retards the water stress syndrome, and that mycorrhizal plants recover faster from moderate and severe water stress than non-mycorrhizal plants. The purpose of this experiment was to investigate the contribution of AMF (Glomus claroideum) to plant tolerance to different water stress treatments and rewatering by monitoring changes in some physiological parameters.

\section{MATERIAL AND METHODS}

Plant material and inoculation: Wheat plants (Triticum aestivum L. cv. 'Buck Pronto') were raised from seeds and individually grown in $2 \mathrm{~L}$ plastic pots filled with $2 \mathrm{~kg}$ of inoculated or not inoculated autoclaved soil. The soil

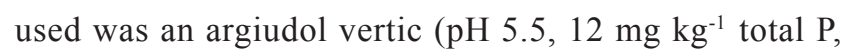
$3.5 \%$ organic matter, $2.0 \%$ total $\mathrm{C}, 0.24 \%$ total $\mathrm{N}$ ), which was sterilized by steaming at $100^{\circ} \mathrm{C}$ for $1 \mathrm{~h}$ on three alternate days.

Glomus claroideum Schenck and Smith isolate (BEG 29) was bulked-up through culture with Trifolium repens L. for four months in a semi-controlled grown chamber. 
The inoculum was a mix of soil, spores $\left(50\right.$ spores $\mathrm{g}^{-1}$ inoculum), mycelium and colonized root fragments. Ten grams of inoculum were added below the seed to inoculated pots at sowing time. Ten grams of sterilized inoculum plus $10 \mathrm{~mL}$ mycorrhizal fungal-free filtrate from the inoculum suspension were added to non-inoculated pots in order to provide the same soil conditions. The experiment was conducted in a semi-controlled growth chamber adjusted to $25 / 20^{\circ} \mathrm{C}$ day/night temperatures, and a $16 \mathrm{~h}$ photoperiod at $350 \mu \mathrm{mol} \mathrm{m} \mathrm{m}^{-2} \mathrm{~s}^{-1}$ of photosynthetic photon flux density (PPFD). Tap water was supplied daily to maintain soil water potential $\left(\Psi_{\mathrm{s}}\right)$ close to field capacity $\left(\Psi_{\mathrm{s}} \sim-0.03 \mathrm{MPa}\right)$ until water stress treatments were started. Symptoms of pest attacks and mineral deficiencies were not observed.

Estimation of AMF colonization: Fungal colonization was evaluated according to Trouvelot et al. (1986) and expressed as percentage of mycorrhization (M\%) and arbuscules development (A\%). The roots were cleared with $10 \% \mathrm{KOH}$ and stained with trypan blue in lactophenol (Phillips and Hayman, 1970). Thirty randomly chosen root fragments of $1 \mathrm{~cm}$ in length were mounted on slides and examined microscopically. Percentage of mycorrhization was calculated as the proportion of infected roots over total root fragments, and $\mathrm{A} \%$ was calculated as the abundance of arbuscules per colonized roots.

Treatments: When root colonization was approximately $50 \%$, inoculated and non-inoculated plants were subjected to the following water stress treatments: (i) control - Plants were watered daily to maintain $\Psi_{\mathrm{s}}$ no lower than $-0.03 \mathrm{MPa}$; (ii) moderate water stress - plants were stressed by withholding water until a $\Psi_{\mathrm{s}}$ of ca. $-0.9 \mathrm{MPa}$ was reached, which took approximately $6 \mathrm{~d}$ (Figure 1); (iii) severe water stress plants were stressed by withholding water until a $\Psi_{\mathrm{s}}$ of ca. -1.8 MPa was reached, which took about $9 \mathrm{~d}$; and (iv) rewatering - half of the plants that were exposed to moderate $\left(\Psi_{\mathrm{s}} \sim-0.9 \mathrm{MPa}\right)$ or severe $\left(\Psi_{\mathrm{s}} \sim-1.8 \mathrm{MPa}\right)$ water stress for $6 \mathrm{~d}$ were then watered to field capacity, which was normally reached within $7 \mathrm{~h}$ (Beltrano et al., 1997). These water potentials were maintained until plant harvest (Figure 1). To control the water levels, $\Psi_{\mathrm{s}}$ was measured daily during the entire experiment with a HR$33 \mathrm{~T}$ dew-point psychrometer (Wescor Inc., Logan, UT,
USA) with PST-55 probes, placed $15 \mathrm{~cm}$ deep in the soil at the beginning of the experiment. Every day the amount of water lost was added to each pot in order to maintain the desired $\Psi_{\mathrm{s}}$. The availability of the soil water was previously determined and a curve of water retention was made.

Variables measured: Ten plants $(n=10)$ of each treatment were harvested at midday as shown in Figure 1.

Biomass production: At harvest, the total plant weight (shoot plus root systems) (DW) was measured after drying in a forced hot-air oven at $80^{\circ} \mathrm{C}$ for $2 \mathrm{~d}$.

Electrolyte leakage: This technique is based on the increase of cellular membrane permeability and concomitantly greater electrolyte diffusion out of cells when leaf tissue is injured by a stress situation. After harvest, the uppermost fully expanded leaves of 10 plants per treatment were immediately cut into discs of $0.8 \mathrm{~cm}$ diameter. The discs were washed briefly three times in deionized water to remove solutes released during cutting of the discs. Five discs of each leaf were then placed in a vial filled with $10 \mathrm{~mL}$ deionized water and

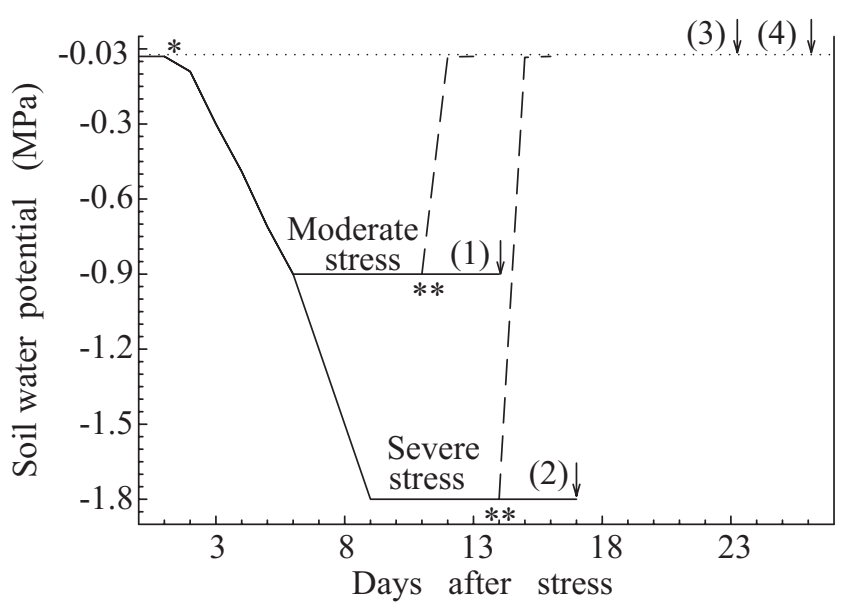

Figure 1. Soil water potential after water stress and rewatering. $\left(^{*}\right)$ Water stress initiated; $(* *)$ Rewatering initiated. Arrows 1, 2, 3 and 4 indicate, respectively, the harvests at moderate water stress, severe water stress, moderate water stress rewatering, and severe water stress rewatering. The dotted line shows the water potential at field capacity, the solid line shows soil drying and the dashed line shows rewatering. 
maintained at $20^{\circ} \mathrm{C}$ for $4 \mathrm{~h}$. Electrolyte leakage was determined by measuring the electrical conductivity of the vial solution, using a conductivity meter and data were expressed as $\mu \mathrm{S} \mathrm{cm}^{-1}$.

Leaf relative water content $(R W C)$ : The RWC was measured in five $0.8 \mathrm{~cm}$ diameter discs of each leaf. The leaf discs, obtained in a similar manner as those used for electrolyte leakage, were weighed, floated on distilled water at $4^{\circ} \mathrm{C}$ in the dark for $4 \mathrm{~h}$, blotted, weighed again and finally dried at $80^{\circ} \mathrm{C}$ for $48 \mathrm{~h}$ for dry weight determination.

\section{Leaf chlorophyll concentration: Chlorophyll} degradation was used as an index of leaf senescence and was determined in one leaf disc $(0.8 \mathrm{~cm}$ diameter $)$ per plant, of each treatment, using the uppermost fully expanded leaf according to Morn and Porath (1980). The results were expressed as $\mu \mathrm{g}$ chlorophyll $\mathrm{cm}^{-2}$.

Total leaf protein concentration: Total leaf protein concentration was determined according to Bradford (1976) in two leaf discs ( $0.8 \mathrm{~cm}$ diameter) per plant of each treatment. The results were expressed as $\mu \mathrm{g}$ protein $\mathrm{cm}^{-2}$.

Experimental design and statistical analysis: Pots were arranged in a completely randomized block design, with 10 replicates for each treatment. Data were statistically analyzed using ANOVA with the software SIGMASTAT 3.1. Comparisons between means were carried out using the Tukey test at $P<0.05$. For percentage values an arcsine transformation was made before statistical analysis.

\section{RESULTS}

Mycorrhizal development: None of the non-inoculated plants was colonized by G. claroideum. Under wellwatered conditions roots showed a significantly higher percentage of mycorrhization compared to waterstressed plants (Table 1). The severe water stress condition decreased the $\mathrm{M} \%$ more than the moderate water stress treatment. The $\mathrm{M} \%$ of rewatered plants was similar to that of well-watered individuals. The A\% decreased with water stress, but it did not recover with the rewatering treatment (Table 1).

Plant growth and physiological parameters: Under wellwatered, moderate and severe water stress conditions,
Table 1. Percentage of mycorrhization (M\%) and arbuscular frequency (A\%) in wheat roots inoculated with Glomus claroideum under well-watered conditions (control) or subjected to moderate or severe water stress and followed by rewatering. Means $(n=10)$ followed by different letters are significantly different $(P<0.001)$.

\begin{tabular}{lcc}
\hline Treatment & M\% & A\% \\
\hline Control & $66 \mathrm{a}$ & $59 \mathrm{a}$ \\
Moderate water stress & $43 \mathrm{~b}$ & $17 \mathrm{~b}$ \\
Moderate water stress plus Rewatering & $54 \mathrm{a}$ & $19 \mathrm{~b}$ \\
Severe water stress & $28 \mathrm{c}$ & $20 \mathrm{~b}$ \\
Severe water stress plus Rewatering & $56 \mathrm{a}$ & $27 \mathrm{~b}$ \\
\hline
\end{tabular}

mycorrhizal inoculation significantly increased total plant dry weight by $15 \%, 17 \%$ and $20 \%$, respectively, compared to non-mycorrhizal plants. Under moderate and severe rewatered conditions total dry weight of mycorrhizal plants was $18 \%$ and $27 \%$ higher than that of non-mycorrhizal plants, respectively (Figure 2).

The leaf RWC of well-watered inoculated plants did not differ from that of the well-watered non-inoculated ones. Moderate water stress reduced RWC by $20 \%$ in both mycorrhizal and non-mycorrhizal plants, and rewatering, on the other hand, increased the RWC by $10 \%$. The inoculation affected RWC when plants were subjected to severe water stress and rewatering, and it was significantly higher in mycorrhizal compared to nonmycorrhizal plants (Figure 3).

The solute leakage of leaves under well-watered conditions did not differ between inoculated and noninoculated plants. Non-mycorrhizal plants, subjected to moderate stress or to severe stress, had significantly higher electrolyte leakage compared with mycorrhizal plants. Rewatering reversed the water stress effects, and in mycorrhizal plants, foliar solute leakage decreased significantly compared with non-mycorrhizal ones (Figure 4).

When plants were subjected to well-watered conditions, leaf chlorophyll concentration was not modified by inoculation. Moderate and severe water stress affected chlorophyll concentration, although values of mycorrhizal plants were significantly higher than those of non-mycorrhizal ones. Rewatered mycorrhizal plants recovered leaf chlorophyll concentration to near the levels in well-watered plants (Figure 5). 


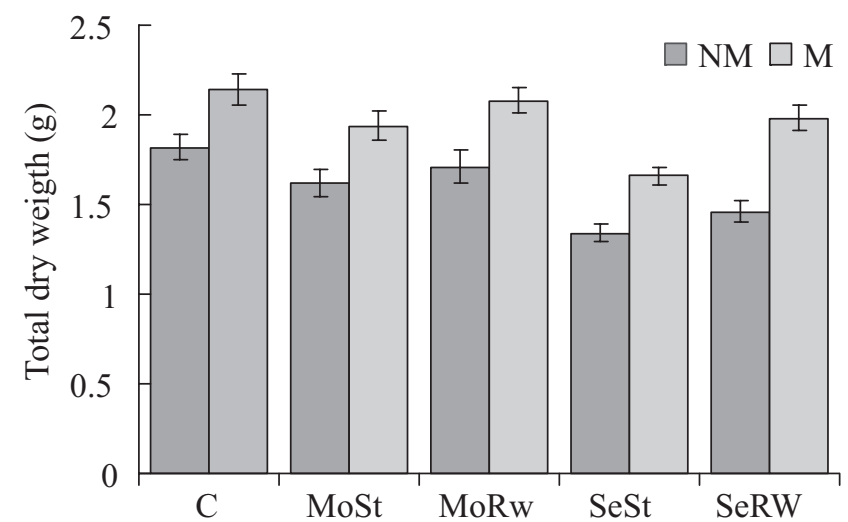

Figure 2. Dry weight per plant in non-mycorrhizal (NM) and mycorrhizal (M) wheat plants inoculated with Glomus claroideum under well-watered conditions $(\mathrm{C})$, moderate water stress $(\mathrm{MoSt})$, severe water stress $(\mathrm{SeSt})$, moderate water stress followed by rewatering (MoRw) or severe water stress followed by rewatering (SeRw). Vertical bars represent SE $(n=10)$.

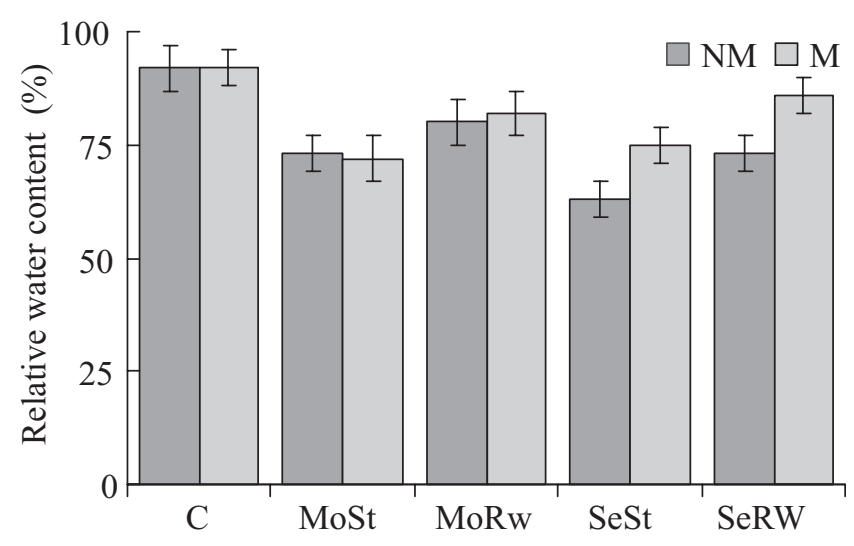

Figure 3. Leaf relative water content in non-mycorrhizal (NM) and mycorrhizal (M) wheat plants inoculated with Glomus claroideum under well-watered conditions (C), moderate water stress (MoSt), severe water stress (SeSt), moderate water stress followed by rewatering (MoRw) or severe water stress followed by rewatering (SeRw). Vertical bars represent $\mathrm{SE}(n=10)$.

There were no significant differences in total leaf protein concentration between inoculated and noninoculated plants, either under well-watered, moderate stress or rewatering conditions. Under severe water stress, mycorrhizal plants showed greater protein concentration than non-mycorrhizal plants (Figure 6).

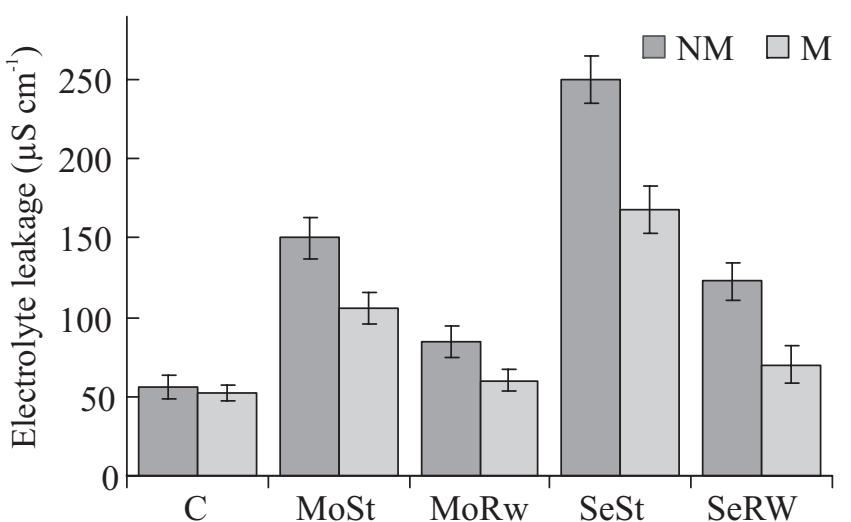

Figure 4. Electrolyte leakage in non-mycorrhizal (NM) and mycorrhizal (M) wheat plants inoculated with Glomus claroideum under well-watered conditions (C), moderate water stress (MoSt), severe water stress (SeSt), moderate water stress followed by rewatering (MoRw) or severe water stress followed by rewatering (SeRw). Vertical bars represent SE $(n=10)$.

\section{DISCUSSION}

Drought severely limits yield of wheat. SánchezBlanco et al. (2004) found that under drought conditions leaf water potential decreased in both non-mycorrhizal and mycorrhizal plants, although this decrease was lower in water-stressed mycorrhizal plants. Symbiosis (AMF) has been shown to increase water deficit tolerance, although the mechanisms involved are contentious (Augé, 2001; Ruiz-Lozano, 2003).

Our results show that $G$. claroideum colonized effectively wheat plants under well-watered conditions. Mycorrhizal colonization ( $\mathrm{M} \%$ and $\mathrm{A} \%$ ) was more adversely affected by severe stress than moderate stress. Rewatering reversed the effect of stress and increased root colonization, and rewatered plants eventually reached control values. However, arbuscles formation did not recover in rewatered plants, probably because arbuscles are assimilated by root cells and their contents are absorbed by the host more rapidly under stress conditions (Kaspari, 1973). While some authors found that water stress affects mycorrhizal symbiotic establishment (Davies et al., 2002; Goicoechea et al., 2005), others such as Bryla and Duniway (1997) reported that drought stress $\left(\Psi_{\mathrm{s}}=-1.5\right.$ to $\left.-2 \mathrm{MPa}\right)$ does not affect mycorrhizal colonization rates in wheat. Braunberger et al. (1994) determined that the hyphae network of AMF 


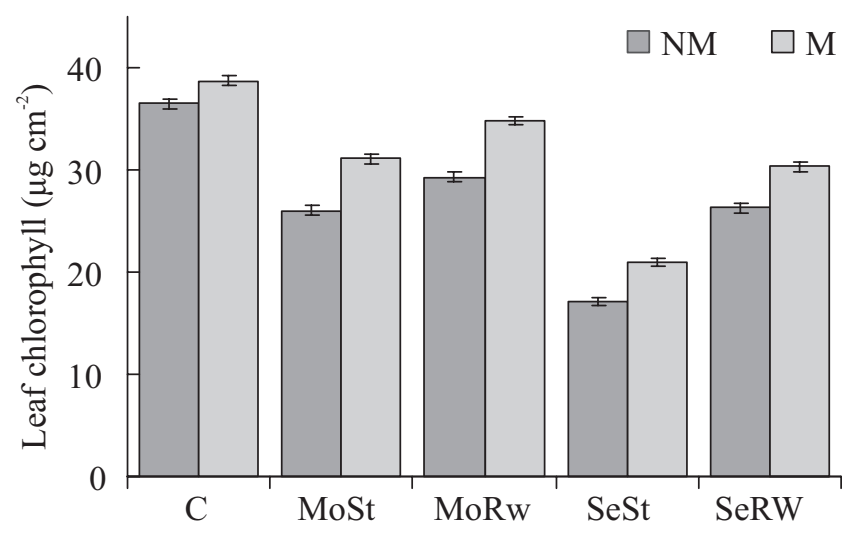

Figure 5. Foliar chlorophyll concentration in nonmycorrhizal (NM) and mycorrhizal (M) wheat plants inoculated with Glomus claroideum under well-watered conditions (C), moderate water stress (MoSt), severe water stress ( $\mathrm{SeSt})$, moderate water stress followed by rewatering (MoRw) or severe water stress followed by rewatering $(\mathrm{SeRw})$. Vertical bars represent $\mathrm{SE}(n=10)$.

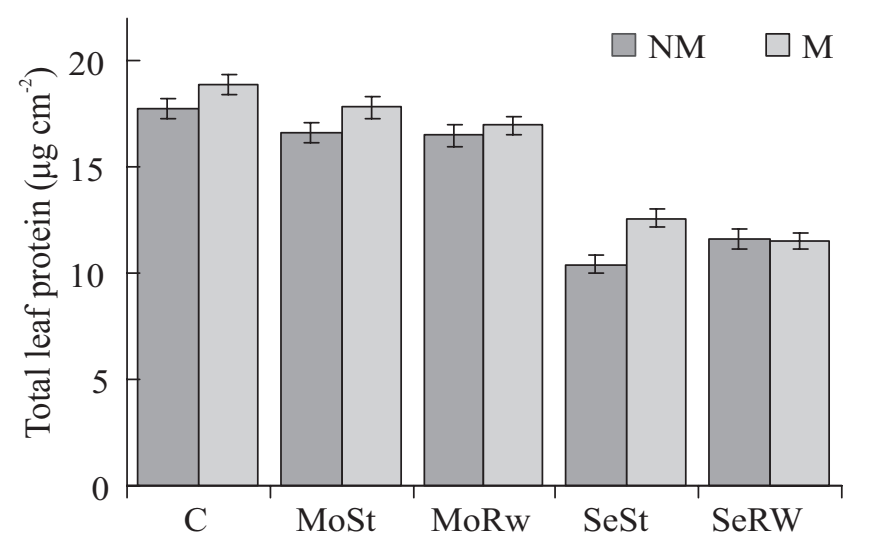

Figure 6. Foliar total protein concentration in nonmycorrhizal (NM) and mycorrhizal (M) wheat plants inoculated with $G$. claroideum under well-watered conditions (C), moderate water stress (MoSt), severe water stress ( $\mathrm{SeSt}$ ), moderate water stress followed by rewatering $(\mathrm{MoRw})$ or severe water stress followed by rewatering $(\mathrm{SeRw})$. Vertical bars represent $\mathrm{SE}(n=10)$.

was capable of surviving and retaining the ability to colonize susceptible roots, even following adverse conditions for plant growth such as water stress.

In this study, inoculation with G. claroideum brought about an important increase in biomass production, which might be attributable to increased dependence of wheat on AMF for water uptake (Al-Karaki et al., 2004).
The AMF symbiosis may improve nutrient uptake by improving exploration of the soil pore space. O'Keefe and Sylvia (1993) observed that external hyphae adhere to soil particles, which would improve contact with the soil solution. Furthermore, they demonstrated that hyphae can access smaller pore spaces than plant roots and root hairs. As soil water content decreases, the relative importance of these factors would increase. Our results show that mycorrhizal symbiosis did not affect the leaf water status of well-watered plants, confirming other results obtained by Sánchez-Blanco et al. (2004) and Goicoechea et al. (2005).

Although water stress treatments reduced leaf RWC, inoculation by $G$. claroideum allowed wheat plants to maintain higher RWC compared with non-mycorrhizal plants, these results are similar to findings by Amerian et al. (2001) in maize plants, inoculated with G. mosseae or $G$. intraradices, and by Panwar (1993), who reported that mycorrhizal symbiosis postpones the relative water content decrease in stressed wheat plants. However, some authors have shown that under drought situations mycorrhizal inoculation did not change leaf RWC (Diallo et al., 2001; Davies et al., 2002; Goicoechea et al., 2005), although in our study similar results were found only under moderate water stress conditions. Moreover, AMF symbiosis can affect the structure, chemistry, and biology of soils (Miller and Jastrow, 2000). Bethlenfalvay and Linderman (1992) have suggested that AMF modification of soil properties may be more important than direct AMF modification of plants, in terms of the mechanisms responsible for AMF effects on plant behavior. In particular, it appears likely that AMF symbiosis may influence soil moisture retention properties (Augè et al., 2001), with consequent effects on plants water relations. In addition, hyphae may increase soil-to-root contact in drying soils (Davies et al., 1992). Better growth of AMF plants in drying soils may be related to improved exploitation of bound water, providing access to soil water below permanent wilting potential (Franson et al., 1991). In our study, during the recovery period leaf RWC of mycorrhizal plants was higher than that of non-mycorrhizal ones, but this is at least partially due to the fact that these plants have higher RWC at the time of rewatering. We observed that mycorrhizal plants were able to postpone the onset of wilting by 2 or $3 \mathrm{~d}$ on moderate or on severe stress 
respectively, in agreement with the results of Panwar (1993) and Amerian et al. (2001). The present results show that inoculation by G. claroideum did not have any effect on total leaf protein concentration either under wellwatered, moderate water stress or rewatering conditions. Under severe water stress inoculated plants increased total protein concentration; a similar trend was found by Ruiz Lozano et al. (1995), who reported that total protein concentrations during drought stress were higher in mycorrhizal than in non- mycorrhizal plants. However, protein accumulation due to this beneficial plant-fungus association has to be further elucidated.

The loss of leaf chlorophyll concentration in wheat plants under water deficit has been reported previously (Beltrano et al., 1999). Our results show that either moderately or severely stressed mycorrhizal plants had significantly higher chlorophyll concentration compared to non-mycorrhizal plants. This is possibly due to the fact that at low soil water potential mycorrhizal plants can absorb more water than non-mycorrhizal ones, as mentioned by Porcel and Ruiz-Lozano (2004). These results are in agreement with those previously found by Sánchez-Blanco et al. (2004) and Morte et al. (2001) who detected higher chlorophyll concentrations in mycorrhizal plants subjected to drought stress. In addition, Mathur and Vyas (2000) concluded that arbuscular mycorrhizal root colonization increased chlorophyll synthesis, which could be associated with higher photosynthesis rates and plant growth. Furthermore, our data demonstrate that rewatered inoculated plants maintained the leaf chlorophyll concentration.

Adverse environmental factors cause cell membranes to lose selective permeability, cellular integrity and capacity for retention of intracellular substances (Lukatkin, 2003). The cellular membrane dysfunction due to water stress causes an increase in the permeability and ion leakage (Beltrano et al., 1999). Our data show that under water stress AMF symbiosis improved membrane integrity, as also noted by Feng et al. (2002) in maize under salinity stress conditions. Mycorrhizal plants also showed significantly diminished cell solute leakage after rewatering, to the extent that inoculated rewatered plant values were close to those of well-watered ones. Our data demonstrate that the normal status of cell membranes is restored more efficiently in mycorrhizal than in non- mycorrhizal plants. i.e. Glomus claroideum could help recover cell membrane permeability in wheat plant leaves.

The increase in cell membranes leakiness is interpreted as an injury and loss of membrane integrity associated with a decreasing RWC, and this might accelerate senescence processes (Thompson, 1988). The higher chlorophyll concentration and the decrease of the solute leakage in inoculated plants, variables used as senescence markers in green tissues, indicated that mycorrhizal activity could protect the plant against drought and postpone the senescence syndrome.

Overall, our data show that mycorrhizal colonization in wheat under water stress conditions has a beneficial effect on water status, enhancing plant water uptake, minimizing the decrease of leaf water content and photosynthetic pigments, and increasing total dry weight. When irrigation was re-established, mycorrhizal plants showed an increase in total dry weight and chlorophyll concentrations, and recovered cell membrane permeability in leaves compared with non-mycorrhizal plants. In conclusion, root colonization by G. claroideum could be an adequate strategy to alleviate the deleterious effects of drought stress and retard the senescence syndrome in wheat.

Acknowledgments: We thank the Banque Europeene des Glomales, INRA Dijon, France for supplying the fungal isolate G. claroideum; Olga Peluso and Laura Wahnan (CONICET) for technical assistance; Cecilia Moreno for the English version; J. J. Guiamet PhD for English revision, Maria del Carmen Ferragine for the abstract translation to Portuguese and the Universidad Nacional de La Plata, CONICET and Comisión de Investigaciones Científicas de la Provincia de Buenos Aires for financial support. J. Beltrano and M. Ronco are researchers of CICBA.

\section{REFERENCES}

Al-Karaki GN, McMichael B, Zak J (2004) Field response of wheat to arbuscular mycorrhizal fungi and drought stress. Mycorrhiza 14:263-269.

Amerian MR, Stewart WS, Griffiths H (2001) Effect of two species of arbuscular mycorrhizal fungi on growth, assimilation and leaf water relations in maize (Zea mays). Aspect Appl. Biol. 63:73-76. 
Augé RM (2001) Water relations, drought and vesiculararbuscular mycorrhizal symbiosis. Mycorrhiza 11:3-42.

Augé RM, Stodola AJW, Tims JE, Saxton AM (2001) Moisture retention properties of a mycorrhizal soil. Plant Soil 230:87-97.

Beltrano J, Carbone A, Montaldi ER, Guiamet JJ (1994) Ethylene as promoter of wheat grain maturation and ear senescence. Plant Growth Regul. 15:107-112.

Beltrano J, Montaldi ER, Bartoli CG, Carbone A (1997) Emission of water stress ethylene in wheat (Triticum aestivum L.) ears: effects of rewatering. Plant Growth Regul. 21:121-126.

Beltrano J, Ronco M, Montaldi ER (1999) Drought stress syndrome in wheat is provoked by ethylene evolution and reversed by rewatering, aminoethoxyvinylglycine, or sodium benzoate. J. Plant Growth Regul. 18:59-64.

Beltrano J, Ronco M, Arango MC (2006) Soil drying and rewatering applied at three grain developmental stages affect differentially growth and grain protein deposition in wheat (Triticum aestivum L.). Braz. J. Plant Physiol. 18:341-350.

Bethlenfalvay GJ, Linderman RG (1992) Mycorrhizae in sustainable agriculture. ASA Special Publication No. 54, ASA, Madison, WI.

Bradford MM (1976) A rapid and sensitive method for the quantitation of microgram quantities of protein utilizing the principle of protein-dye binding. Anal. Biochem. 71:248-254.

Braunberger PG, Abbott LK, Robson AD (1994) The effect of rain in the dry season on the formation of vesiculararbuscular mycorrhizas in the growing season of annual clover-based pastures. New Phytol. 127:107114.

Bryla DR, Duniway JM (1997) Growth, phosphorus uptake, and water relations of safflower and wheat infected with an arbuscular mycorrhizal fungus. New Phytol. 136:581-590.

Davies FT Jr, Potter JR, Linderman RG (1992) Mycorrhiza and repeated drought exposure affect drought resistance and extraradical hyphae development of pepper plants independent of plant size and nutrient content. J. Plant Physiol. 139:289-294.

Davies FT Jr, Olalde-Potugal V, Aguilera-Gomez L, Alvarado MJ, Ferrera-Cerrato RC, Boutton TW (2002) Alleviation of drought stress of Chile ancho pepper (Capsicum annum L. Cv. San Luis) with arbuscular mycorrhiza indigenous to Mexico. Sci. Hort. 92:347-359.

Diallo AT, Samb PI, Roy-Macauley H (2001) Water status and stomatal behaviour of cowpea, Vigna unguiculata (L.) Walp, plants inoculated with two Glomus species at low soil moisture levels. Eur. J. Soil Biol. 37:187-196.

Feng G, Zhang F, Li X, Tian C, Tang C, Rengel Z (2002) Improved tolerance of maize plants to salt stress by arbuscular mycorrhiza is related to higher accumulation of soluble sugars in roots. Mycorrhiza 12:185-190.

Franson RL, Milford SB, Bethlenfalvay GJ (1991) The Glycine-Glomus-Bradyrhizobium symbiosis. XI. Nodule gas exchange and efficiency as a function of soil and root water status in mycorrhizal soybean. Physiol. Plant. 83:476-482.

Goicoechea N, Merino S, Sánchez-Díaz M (2005) Arbuscular mycorrhizal fungi can contribute to maintain antioxidant and carbon metabolism in nodules of Anthyllis cytisoides L. subjected to drought. J. Plant Physiol. 162:27-35.

Hetrick BAD, Wilson GWT, Todd TC (1996) Mycorrhizal response in wheat cultivars: relationship to phosphorus. Can. J. Bot. 74:19-25.

Jeffries P, Gianinazzi S, Perotto S, Turnau K, Barea JM (2003) The contribution of arbuscular mycorrhizal fungi in sustainable maintenance of plant health and soil fertility. Biol. Fertil. Soils. 37:1-16.

Kaspari H (1973) Elektronenmikroskopische Untersuchung zur Feinstruktur der endotrophen Tabacmykorrhiza. Arch. Mikrobiol. 92:701-707.

Lukatkin AS (2003) Contribution of oxidative stress to the development of cold-induced damage to leaves of chilling-sensitive plants: 3 . Injury of cell membranes by chilling temperatures. Russian J. Plant Physiol. 50:243-246.

Martineau JR, Specht JE, Williams JH, Sullivan CY (1979) Temperature tolerance in soybeans. I. Evaluation of a technique for assessing cellular membrane thermostability. Crop Sci. 19:75-78.

Mathur N, Vyas A (2000) Influence of arbuscular mycorrhizae on biomass production, nutrient uptake and physiological changes in Ziziphus mauritana Lam. under water stress. J. Arid Environ. 45:191-195.

Miller RM, Jastrow JD (2000) Mycorrhizal fungi influence soil structure. In: Kapulnik Y, Douds DD (eds), Arbuscular Mycorrhizas: Physiology and Function, 
pp.3-18. Kluwer Academic Publishers. Dordrecht.

Morn R, Porath D (1980) Chlorophyll determination in intact tissues using N,N-dimethylformamide. Plant Physiol. 65:478-479.

Morte A, Díaz G, Rodríguez P, Alarcón JJ, Sánchez-Blanco MJ (2001) Growth and water relations in mycorrhizal and nonmycorrhizal Pinus halepensis plants in response to drought. Biol. Plant. 44:263-267.

Navarri-Izzo F, Quartacci MF, Melfi D, Izzo R (1993) Lipid composition of plasma membranes isolated from sunflower seedlings grown under water stress. Physiol. Plant. 87:508-514.

O'Keefe DM, Sylvia DM (1993) Seasonal dynamics of the association between sweet potato and vesiculararbuscular mycorrhizal fungi. Mycorrhiza 3:115-122.

Panwar JD (1993) Response of VAM and Azospirillum inoculation to water status and grain yield in wheat under water stress condition. Indian J. Plant Physiol. 36:41-43.

Phillips JM, Hayman DS (1970) Improved procedure of clearing roots and staining parasitic and vesicular arbuscular mycorrhizal fungi for rapid assessment of infection. Trans. Br. Mycol. Soc. 55:159-161.

Porcel R, Ruiz-Lozano JM (2004) Arbuscular mycorrhizal influence on leaf water potential, solute accumulation, and oxidative stress in soybean plants subjected to drought stress. J. Exp. Bot. 55:1743-1750.

Ruiz-Lozano JM (2003) Arbuscular mycorrhizal simbiosis and alleviation of osmotic stress. New perspectives for molecular studies. Mycorrhiza 13:309-317.

Ruiz-Lozano JM, Azcón R, Gómez M (1995) Effects of arbuscular-mycorrhizal Glomus species on drought tolerance: physiological and nutritional plant responses. Appl. Environ. Microbiol. 61:456-460.

Saadalla MM, Shanahan JF, Quick JS (1990) Heat tolerance in winter wheat: I. Hardening and genetic effects on membrane thermostability. Crop Sci. 30:1243-1247.

Sánchez-Blanco MJ, Fernández T, Morales MA, Morte A, Alarcón JJ (2004) Variations in water status, gas exchange, and growth in Rosmarinus officinalis plants infected with Glomus deserticola under drought conditions. J. Plant Physiol. 161:675-682.

Sullivan CY (1972) Mechanisms of heat and drought resistance in grain sorghum and methods of measurement. In: Rao NGP, House LR (eds), Sorghum in the Seventies. pp.247-264. Oxford and India Book House, New Delhi.

Sullivan CY, Ross WM (1979) Selecting for drought and heat resistance in grain sorghum. In: Mussell $\mathrm{H}$, Staples R (eds), Stress Physiology in Crop Plants. pp.263-281. John Wiley \& Sons, New York.

Thompson JE (1988) The molecular basis for membrane deterioration during senescence. In: Nooden LD, Leopold AC (eds), Senescence and Aging in Plants, pp.51-83. Academic Press, San Diego.

Trouvelot A, Kough J, Gianinazzi-Pearson V (1986) Mesure du taux de mycorrhization VA d'un systeme radiculaire. Recherche de methodes d'estimation ayant une signification fonctionnelle. In: Gianinazzi-Pearson V, Gianinazzi S (eds), Mycorrhizae: Physiological and Genetical Aspects, pp.217-221. INRA-Press, Paris. 